\title{
Diagnosis dan Penatalaksanaan Low Risk Papillary Thyroid Carcinoma
}

\author{
Lorensia Fitra Dwita ${ }^{1}$, Sukri Rahman ${ }^{2}$, Hera Novianti $^{3}$
}

\begin{abstract}
Abstrak
Papillary Thyroid Carcinoma (PTC) adalah jenis tumor ganas kelenjar tiroid yang sering terjadi dengan pola pertumbuhan yang papiler. Standar baku penegakkan diagnosis PTC adalah dengan gambaran histopatologi dan Fine Needle Aspiration Biopsy (FNAB). Penatalaksanaan sesuai dengan indikasinya dapat berupa ismolobektomi ataupun total tiroidektomi. Dilaporkan kasus perempuan berusia 29 tahun dengan diagnosis low risk papillary thyroid carcinoma stadium II (T2NOMO) dan dilakukan ismolobektomi sinistra. Diagnosis low risk papillary thyroid carcinoma ditegakkan dengan pemeriksaan FNAB dan histopatologis. PTC unilateral ditatalaksana dengan ismolobektomi. Sebagian besar PTC memiliki prognosis yang baik,namun tetap dibutuhkan kontrol secara periodik pasca tindakan operatif
\end{abstract}

Kata kunci: FNAB, ismolobektomi, PTC, resiko rendah

\begin{abstract}
Papillary Thyroid Carcinoma (PTC) is often happened among all of thyroid gland malignancy, with papillary growth patterns cell. Definite diagnosis of PTC was accomplished by Fine Needle Aspiration Biopsy (FNAB) and histopathology. The treatment is depended on its indication (isthmolobectomy or total thyroidectomy). It has been reported a 29 years old woman with diagnosis of low-risk papillary thyroid carcinoma stage II (T2NOMO) and treated with isthmolobectomy procedure. Definite diagnosis of papillary thyroid carcinoma was accomplished through FNAB and histopathology. Unilateral PTC was treated with isthmolobectomy. Even though almost all PTC has an excellent prognosis, a periodic follow up after surgery is still needed..
\end{abstract}

Keywords: FNAB, isthmolobectomy, PTC, low-risk

Affiliasi penulis: ${ }^{1}$ Program Pendidikan Dokter Spesialis THT-KL, Fakultas Kedokteran, Universitas Andalas, Padang, Indonesia. ${ }^{2}$ Bagian THT-KL, Fakultas Kedokteran, Universitas Andalas, Padang, Indonesia. ${ }^{3}$ Bagian Patologi Anatomi, Fakultas Kedokteran, Universitas Andalas, Padang, Indonesia. Korespondensi: Sukri Rahman, Email: sukrirahman@med.unand.ac.id Telp: 085363448244

\section{PENDAHULUAN}

Tumor ganas tiroid adalah jenis keganasan endokrin yang paling sering terjadi dan angka kejadiannya meningkat secara pesat. ${ }^{1,2}$ Insiden tumor ganas tiroid meningkat 3-4 : 1 pada perempuan dan merupakan keganasan nomor 6 terbanyak pada perempuan di dunia. ${ }^{1}$ Sekitar $77 \%$ tumor ganas tiroid terjadi pada perempuan dan $90 \%$ nya adalah tipe differentiated. $^{2}$ Kebanyakan tumor tiroid terdiagnosis selama dekade 3-6 kehidupan. ${ }^{1}$ Sebagian besar tumor ganas tiroid adalah tumor epitel yang berasal dari sel folikuler tiroid. Tumor ganas ini berkembang menjadi tiga tipe secara patologi yaitu Papillary Thyroid Carcinoma (PTC), Follicular Thyroid Carcinoma (FTC), Medullary Thyroid Carcinoma (MTC) dan Anaplastic Thyroid Carcinoma (ATC) ${ }^{1,2,3}$

\section{Kelenjar Tiroid}

Kelenjar tiroid terdiri atas dua lobus lateral yang dihubungkan oleh ismus dan terletak sejajar dengan kartilago trakea 2-4. Masing-masing lobus tiroid berukuran $4 \times 1,5 \times 2 \mathrm{~cm} .{ }^{4,5}$ Kelenjar tiroid dewasa berwarna coklat dan padat, berlokasi di posterior strap muscles. Kelenjar tiroid normal mempunyai berat sekitar 20 gram, namun bervariasi tergantung berat badan dan intake iodine. $^{6}$

Produksi dan sekresi hormon tiroid diatur oleh TSH (Thyroid Stimulating Hormone) dari kelenjar 
hipofisis. Peningkatan kadar TSH bias memicu pembesaran dan hipervaskularisasi kelenjar tiroid. ${ }^{(4,5)}$ Hormon tiroid memiliki peranan penting pada proses tumbuh kembang, diferensiasi saraf, metabolisme., Kelenjar tiroid terbentuk dari folikel yang selektif menyerap dan menyimpan iodine untuk menghasilkan hormon tiroid. Folikel ini terdiri atas satu lapisan sel epitel tiroid yang menyekresikan hormon tiroid (Triiodotironin/T3) dan Tiroksin (T4). ${ }^{9}$

\section{Tumor Ganas Tiroid}

Tumor ganas tiroid tidak memiliki etiologi yang nyata, melainkan memiliki faktor risiko yang memicu terjadinya tumor ganas tiroid diantaranya adalah riwayat paparan radiasi saat usia anak-anak, terutama pada usia dibawah 5 tahun, obesitas, defisiensi iodium, genetik. ${ }^{10,11}$ Berdasarkan anamnesis dan pemeriksaan fisik, Jatin Shah 2012 merangkum penegakkan diagnosis dan tatalaksana massa tiroid dalam algoritma gambar 1. Pasien dengan massa tiroid dapat ditentukan termasuk pada tingkatan (grade) risiko tinggi atau rendahnya untuk suatu keganasan tiroid (Tabel 1). ${ }^{3}$ Berdasarkan stratifikasi kelompok risiko tersebut dan karakteristik tumor bisa dijadikan sebagai petunjuk penatalaksanaan tumor ganas tiroid dan prognosisnya. ${ }^{3}$

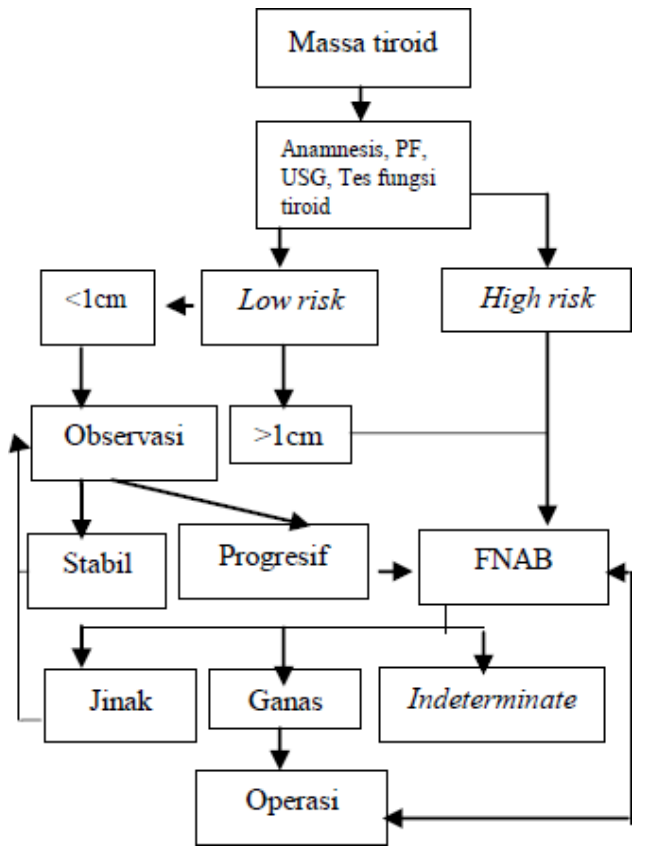

Gambar 1. Algoritma manajemen massa tiroid. ${ }^{3}$
Pemeriksaan Fine Needle Aspiration Biopsy (FNAB) memiliki peranan penting pada evaluasi nodul tiroid. ${ }^{10}$ Jika hasil pemeriksaan FNAB menyatakan massa jinak atau meragukan, maka dibutuhkan pemeriksaan USG rutin yang dilakukan secara interval tertentu berdasarkan pemeriksaan klinis untuk pemantauan lebih lanjut. ${ }^{3}$

Tabel 1. Risiko keganasan tiroid ${ }^{3}$

\begin{tabular}{|c|c|}
\hline $\begin{array}{c}\text { Risiko Rendah } \\
\text { (low-risk) }\end{array}$ & $\begin{array}{c}\text { Risiko Tinggi } \\
\text { (high-risk) }\end{array}$ \\
\hline Perempuan & Laki-laki \\
\hline Dewasa muda & Usia tua/anak-anak \\
\hline Ukuran $<1 \mathrm{~cm}$ & $\begin{array}{l}\text { Massa solid dan } \\
\text { besar }\end{array}$ \\
\hline $\begin{array}{ll}\text { Ukuran } & \text { tidak } \\
\text { bertambah }\end{array}$ & $\begin{array}{l}\text { Ukuran bertambah } \\
\text { progresif }\end{array}$ \\
\hline Multinodul atau kistik & $\begin{array}{l}\text { Adanya } \\
\text { limfadenopati }\end{array}$ \\
\hline Asimptomatik & Simtomatik \\
\hline $\begin{array}{l}\text { Hasil FNAB jinak } \\
\text { (benign) }\end{array}$ & $\begin{array}{l}\text { Tumor ganas Tiroid } \\
\text { sebelumnya }\end{array}$ \\
\hline TSH rendah & Riwayat radiasi \\
\hline
\end{tabular}

Setelah dilakukan pemeriksaan FNAB, idealnya dilaporkan dalam enam kategori yang disebut dalam Bethesda System, yaitu: kategori nondiagnostic (unsatisfactory) dengan resiko keganasan 1- 4\%, benign dengan resiko keganasan 0-3\%, Atypia of Undetermined Significance (AUS) dengan resiko keganasan 5-15\%, Follicular neoplasm or suspicious (FLUS) dengan resiko keganasan $15-30 \%$, suspicious malignancy dengan resiko keganasan $60-75 \%$ dan malignancy dengan resiko keganasan 97-99\%. Kegunaan Bethesda System ini adalah bisa dijadikan sebagai penuntun langkah diagnostik berikutnya dan perencanaan tatalaksana pada tumor ganas tiroid. ${ }^{6,12}$ American Joint Commitee on Cancer (AJCC) 2017 telah memperkenalkan penegakkan stadium terbaru untuk tumor tiroid baik tipe differentiated dan anaplastic dengan indikator usia meningkat menjadi >55 tahun dengan penentuan stadiumnya dilihat dari tiga aspek yaitu Primary Tumor (T), Regional Lymph Node (N) dan Distant Metastasis (M). ${ }^{13}$ 


\section{Papillary Thyroid Carcinoma (PTC)}

Papillary Thyroid Carcinoma (PTC) pada tampilan makroskopis berwarna abu-abu/putih dengan ukuran bervariasi disertai tepi yang infiltratif, berkapsu dan memiliki kalsifikasi. Pada tampilan mikroskopis, PTC mempunyai struktur papilar dengan inti yang fibrovaskular dengan nukleus yang berbentuk oval. ${ }^{14}$ Disertai nuclear feature yang lebih diagnostik adalah tampilannya yang bersih, ground-glass. ${ }^{1,12}$ PTC memiliki beberapa varian yang secara garis besar dibagi berdasarkan sifatnya yaitu varian agresif (tall cell variant, columnar cell variant, hobnail variant), less favorable (solid variant, diffuse sclerosing variant), favorable (follicular encapsulated, cribriform-morular variant, Warthin-like variant). ${ }^{14}$

Pemeriksaan penunjang lain adalah modalitas radiologis, dapat dilakukan dengan Ultrasonografi (USG), Computed- Tomography Scan (CT Scan), Magnetic Resonance Imaging (MRI), Tiroid Scan Technetium-99 (Tc 99) atau lodine-131, dan Fluorodeoxyglucose-18 (FDG) PET Scan. USG adalah modalitas yang paling sering digunakan untuk evaluasi awal kelenjar tiroid dan kelenjar getah bening regional. $^{3}$

Suatu studi dilakukan pada 2441 pasien, didapatkan nodul tiroid teraba pada 169 pasien, sedangkan dari pemeriksaan USG dideteksi nodul pada 249 pasien. ${ }^{14}$ Pemeriksaan USG lebih dipilih dan dipercaya untuk evaluasi nodul. Pemeriksaan USG pada Papillary Thyroid Carcinoma sebagai bentuk keganasan tiroid yang paling banyak ditemukan akan memberikan hipoekoik, mikrokalsifikasi, batas yang microlobulated atau spiculated. ${ }^{3,14}$ Pemeriksaan CT Scan dibutuhkan jika rencana tatalaksana operasi dilakukan pada pasien dengan perluasan tumor ke ekstratiroid yang melibatkan laring atau trakea. ${ }^{15}$

Penatalaksanaan efektif pada neoplasma tiroid dan nodul tiroid yang simtomatik adalah pembedahan dan beberapa dilanjutkan dengan terapi radioaktif lodine-131 (RAI) sebagai terapi adjuvan. Beberapa pendekatan yang bisa dilakukan dalam tindakan operatif keganasan tiroid adalah tiroidektomi total dengan atau tanpa diseksi leher, tiroidektomi total minimally-invasive dengan endoskopik, dan lobektomi/ismolobektomi. ${ }^{3,11}$
Pada pasien dengan low-risk type tatalaksana yang ideal adalah lobektomi ipsilateral. Sedangkan total tiroidektomi dilakukan pada pasien dengan tumor bilateral, atau pada pasien dengan low-risk namun ada riwayat paparan radiasi sebelumnya, riwayat keluarga dengan tumor ganas tiroid dan penyebaran kelenjar getah bening regional. ${ }^{3,16}$

\section{Komplikasi Pasca Tiroidektomi}

Komplikasi pasca tiroidektomi bisa terjadi secara sementara (transien) dan menetap (permanen), diantaranya adalah perdarahan pasca operasi, infeksi, disfonia (neuropraksia nervus laringeal rekuren atau cabang superior nervus laringeal), hipokalsemia (akibat trauma pada kelenjar paratiroid) dan hipoparatiroidisme. Perdarahan pasca tiroidektomi terjadi pada $0,36 \%$ - 4,3\% dan menunjukkan gejala klinis seperti sesak nafas, ekimosis, pembengkakan leher dan disfagia. ${ }^{11,17}$

\section{Prognosis}

Terdapat beberapa sistem stratifikasi prognostik yang pernah digunakan, yaitu: ${ }^{11}$ EORTC (European Organization for Research and Treatment Of Cancer), AGES (Age, Grade, Extension, Size), AMES (Age, Metastases, Extent, Size) dan GAMES (Grade, Age, Metastases, Extensors, Size) dikembangkan dari Memorial Sloan Kettering Cancer Center (MSKCC) membagi menjadi 3 kelompok yaitu low-risk ( usia $<45$ tahun, dengan ukuran massa $<4 \mathrm{~cm}$, intraglandular dan tidak disertai dengan metastasis), intermediate risk (usia $<45$ tahun dengan ukuran massa $>4 \mathrm{~cm}$, ekstraglandular, dengan adanya metastasis, atau usia $>45$ tahun dengan ukuran massa $<4 \mathrm{~cm}$, intraglandular dan tidak disertai metastasis) dan high-risk (usia $>45$ tahun). ${ }^{3,15}$

\section{Follow-up}

Pemantauan pasca operasi dilakukan dari tiga aspek, biokemikal, fungsional dan struktur (anatomi). Oleh karena prognosis dari tumor ganas tiroid tergantung pada jenis bentuk diferensiasi sel, semakin buruk diferensiasi sel maka prognosisnya pun semakin memburuk. ${ }^{3}$ Penilaian biokemikal bisa dilihat dari kadar serum Tiroglobulin (TGb). Jika kadar TGb 6 
minggu pasca operasi adalah > $1 \mathrm{ng} / \mathrm{ml}$ maka diindikasikan untuk dilakukan terapi adjuvan RAI ablasi. ${ }^{3,11}$

Penilaian fungsional pada pasien dengan terapi Radioaktif lodine (RAI). Pemeriksaan tracer scan dilakukan 1 minggu setelah tindakan operatif untuk menilai residu/sisa tumor. ${ }^{3,10}$ Penilaian struktur (anatomi) yang sering digunakan adalah pemeriksaan USG yang dianjurkan setiap 6-12 bulan pasca operasi dan setiap tahun setelahnya selama 4-5 tahun pertama. $^{3,17}$

\section{KASUS}

Seorang wanita 29 tahun datang ke poliklinik THT-KL RSUP Dr. M. Djamil Padang pada bulan Januari 2018 dengan keluhan benjolan di leher bagian depan sisi kiri yang semakin membesar sejak 2 bulan sebelum masuk rumah sakit. Sebelumnya benjolan dirasakan sudah sejak 1 tahun sebelum masuk rumah sakit, awalnya benjolan sebesar kelereng dan makin membesar menjadi sebesar telur ayam. Benjolan tidak disertai nyeri, memerah dan tidak mengeluarkan cairan atau darah. Riwayat tangan sering gemetaran ada sejak 1 tahun yang lalu. Riwayat sering keringatan ada sejak 1 tahun yang lalu. Riwayat sering konsumsi makanan kaya yodium (ikan, garam beryodium) tidak diketahui. Keluhan tidak disertai suara serak, sesak nafas, dan dada rasa berdebar-debar. Tidak ada mata menonjol dan tidak terdapat penurunan berat badan yang drastis. Nyeri dan sukar menelan tidak dikeluhkan. Riwayat pengobatan dengan penyinaran pada daerah leher sebelumnya tidak ada. Riwayat trauma pada leher disangkal. Pasien tidak tinggal di daerah pegunungan. Tidak ada anggota keluarga dengan keluhan yang sama dan tidak ada riwayat keganasan di keluarga

Pada pemeriksaan umum, kondisi umum sedang, tanda vital dalam batas normal. Dihitung Indeks Massa Tubuh (IMT) pasien dalam batas normal $(19,2)$. Pada pemeriksaan fisik telinga, hidung dan tenggorok tidak ditemukan kelainan.Pada pemeriksaan fisik regio colli anterior secara palpasi teraba massa solid ukuran $25 \mathrm{x}$ $10 \times 10 \mathrm{~mm}$, kenyal padat, berbatas tidak tegas, permukaan berbenjol-benjol, tidak disertai nyeri tekan, dan ikut bergerak saat menelan. Tidak teraba
Gambar 2. roto pasien sebelum operası

Pembesaran kelenjar getah bening (Gambar 2) yang dilakukan pemeriksaan darah lengkap dan fungsi tiroid dalam batas normal.

Pemeriksaan USG Tiroid didapatkan nodul hipoekoik di ismus-lobus kiri tiroid, batas tidak tegas, tepi ireguler ukuran 2,3 x 1,5 x 2,3 cm dengan kalsifikasi minimal. Pada pemeriksaan dengan Doppler, flow vascular intranodul meningkat. Tiroid kanan dalam batas normal. Tampak KGB regio colli kiri ukuran 0,8 x 0,3 cm dan 0,5 x 0,3 cm disertai hillus. Kesan nodul solid tiroid kiri-ismus dengan limfadenopati regio colli kiri.

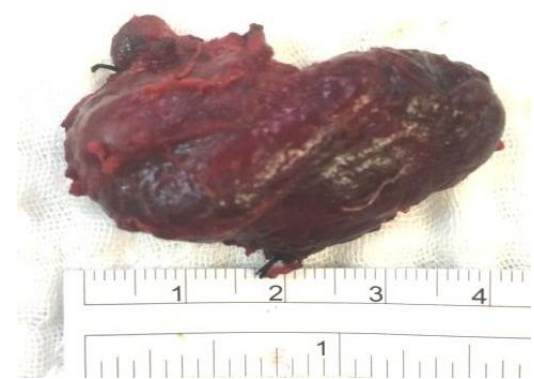

Gambar 3. Kelompokkan sel dengan inti bulat-oval, sebagian besar sel ini tumbuh papiler.

Dilakukan pemeriksaan FNAB dengan hasil tampak sebaran dan kelompokan sel dengan inti bulatoval, adanya vakuol intranuklear dan beberapa sel dengan nuclear groove, sebagian besar sel ini tumbuh papiler. Kesan pappilary thyroid carcinoma(Gambar 3).

Pada penentuan stadium pada pasien in didapatkan ukuran tumor 2-4 cm tanpa pembesaran kelenjar getah bening dan penyebaran jauh, pasien seorang wanita dengan usia $<45$ tahun maka pasien didiagnosis kerja dengan low risk papillary thyroid carcinoma stadium II (T2NOM0). 


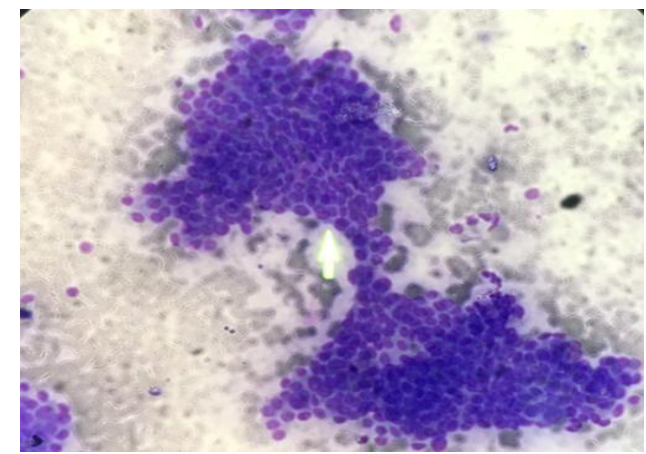

Gambar 4. Lobus tiroid kiri dengan ismus berwarna merah kecoklatan

Pada tanggal 13 Maret 2018, pasien menjalani ismolobektomi sinistra. Pasien tidur dalam posisi supinasi dengan kepala hiperekstensi. Dilakukan tindakan aseptik dan antiseptik pada lapangan operasi. Dilakukan penandaan insisi horizontal tepat di atas massa dengan jarak dua jari atas fossa suprasternal, kemudian dilakukan infiltrasi dengan epinefrin 1:200.000 pada daerah insisi. Insisi diperdalam hingga m.platisma, dibuat flap ke atas sampai kartilago tiroid notch dan ke bawah sampai sternal notch. Otot pre trakealis (sternohyoid dan sternotiroid) dipisahkan ke arah lateral dengan melepaskannya dari kapsul tiroid. Tampak lobus tiroid kiri yang berbenjol- benjol. Bebaskan kelenjar tiroid bagian lateral, bagian superior. Ligasi arteri tiroid superior dan vena tiroid superior.Fasia pretrakeal ditembus dan bebaskan tiroid dari fasia trakea ke sisi kontralateral, dan dilakukan transeksi ismus. Dilakukan eksisi ismus dan lobus tiroid kiri secara komplit. Perdarahan dirawat, dipasang drain, luka dijahit lapis demi lapis, operasi selesai. Lobus tiroid yang dieksisi berukuran 40×30×10 mm (Gambar 4) diperiksakan histopatologisnya.Pasca operasi, pasien diberikan terapi injeksi seftriakson 2x1 gram (IV), drip tramadol $50 \mathrm{mg} / \mathrm{kolf}$ dalam $\mathrm{RL} 8$ jam/kolf, injeksi deksametason $3 \times 5 \mathrm{mg}$ (IV) dan injeksi asam traneksamat $3 \times 500 \mathrm{mg}$ (IV)

Follow up hari pertama, tidak ada suara serak dan sesak nafas, gangguan menelan tidak ada, demam tidak ada, batuk berdarah tidak ada, terdapat nyeri pada regio operasi minimal. Pada regio colli anterior, luka operasi tertutup perban, darah merembes tidak ada, drain $\pm 8 c c$. Terapi dilanjutkan. Follow-up hari ketiga, pasien tidak ada keluhan, kecuali masih terasa nyeri di regio operasi. Perban diganti, drain dilepas dan pada regio colli anterior didapatkan luka operasi tenang tidak terdapat hematom dan tanda infeksi. Terapi seftriakson $2 \times 1$ gram (IV) dilanjutkan, drip tramadol, injeksi deksametason, injeksi asam traneksmat dihentikan. Hari keempat pasien dipulangkan

Follow up hari ketujuh pasca operasi, suara serak tidak ada, nyeri tidak ada. Pada pemeriksaan fisik tidak ditemukan kelainan, dan jahitan operasi dilepas. Luka bekas operasi tenang. Pasien membawa hasil pemeriksaan histopatologis dengan kesan papillary thyroid carcinoma. Follow up bulan kedua, pasien tidak ada keluhan (Gambar 5). Pasien telah dilakukan pemeriksaan ulang fungsi tiroid dan pemeriksaan Tiroglobin dengan hasil normal.

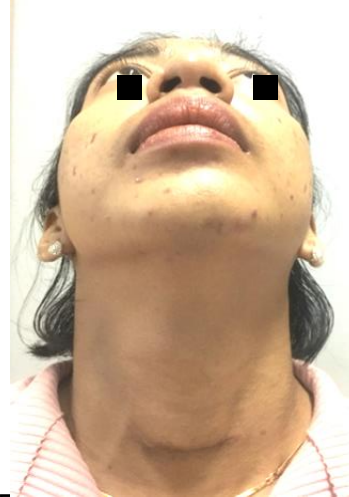

Gambar 5. Foto pasien 2 bulan post-operasi

\section{PEMBAHASAN}

Dilaporkan kasus seorang wanita berusia 29 tahun datang ke Poliklinik THT-KL RSUP dr M Djamil Padang dengan diagnosis low risk papillary thyroid carcinoma stadium II (T2N0M0). Diagnosis ditegakkan berdasarkan anamnesis, pemeriksaan fisik, pemeriksaan USG dan histopatologi. Pasien ditatalaksana sesuai stadium tumor ganas tiroid dengan ismolobektomi sinistra.

Berdasarkan studi Mahmud didapatlan insiden tumor ganas tiroid terjadi 3,7 per 100.000 penduduk dengan rasio jenis kelamin perempuan : laki-laki adalah 2:1 dan sebagian besar bentuk variannya adalah Papillary Thyroid Carcinoma (PTC). ${ }^{18}$ Sama halnya dengan Shah, ${ }^{3}$ yang menyatakan lebih dari $90 \%$ tumor ganas tiroid adalah tipe differentiated (papillary dan follicular). Pada kasus ini, pasien adalah 
seorang perempuan berusia 29 tahun dengan diagnosis papillary thyroid carcinoma.

Diagnosis tumor ganas tiroid bisa ditegakkan berdasarkan anamnesis, pemeriksaan fisik sederhana, pemeriksaan radiologis seperti USG, CT Scan dan pemeriksaan histopatologi. Pada studi Livolsi dinyatakan bahwa USG merupakan pemeriksaan yang dapat dihandalkan untuk evaluasi nodul yang sukar dipalpasi. ${ }^{11}$ Pada kasus ini telah dilakukan pemeriksaan USG tampak gambaran nodul hipoekoik di ismus-lobus kiri tiroid, batas tidak tegas, tepi ireguler ukuran 2,3 x 1,5 x 2,3 cm. Sesuai algoritma diagnostik nodul tiroid, dinyatakan massa tiroid yang tampak pada USG berukuran > $1 \mathrm{~cm}$ pada individu low-risk type (wanita,usia < 45tahun, massa $<4 \mathrm{~cm}$, tidak disertai perluasan ekstratiroid) maka dilakukan pemeriksaan FNAB.

Pada pemeriksaan FNAB didapatkan hasil sesuai dengan papillary thyroid carcinoma. Penentuan stadium baku distandardisasikan dari AJCC 2017, pada kasus ini pasien dengan low risk papillary thyroid carcinoma stadium II (T2N0M0) dengan ukuran tumor 2-4 cm, tidak ditemukan pembesaran kelenjar getah bening dan tidak disertai dengan metastasis jauh. Sesuai dengan tatalaksana yang telah distandardisasikan dari NCCN Thyroid 2017, pasien ini dengan papillary thyroid carcinoma yang memenuhi seluruh kriteria indikasi dilakukannya lobektomi, yaitu tanpa ada riwayat paparan radiasi sebelumnya, tidak disertai penyebaran regional dan jauh, tidak mengalami perluasan ekstra tiroid dan ukuran tumor $\leq$ $4 \mathrm{~cm}$.

Beberapa kelompok prognosis yang digunakan untuk tumor ganas tiroid adalah EORTC, AGES, AMES, GAMES. Kelompok prognosis yang dipakai bervariasi tergantung pada ahli tersebut. AJCC 2017 menyatakan sistem stadium dan prognostik pada tumor ganas tiroid masih merujuk pada data Memorial Sloan Kettering Cancer Center (MSKCC) yaitu GAMES (Grade, Age, Metastases, Extensors, Size). ${ }^{15}$ Sistem prognostik GAMES juga digunakan untuk studi follow-up pasien pasca lobektomi tanpa radioablasi pada low-risk papillary thyroid carcinoma selama ratarata 17,6 tahun dengan angka bertahan hidup selama 25 tahun adalah $95,2 \%{ }^{19}$
Shah menyatakan bahwa perlu dilakukan kontrol pemeriksaan USG tiroid dan dianjurkan setiap 6-12 bulan pasca operasi dan setiap tahun setelahnya selama 4-5 tahun pertama. ${ }^{3}$ Jika tidak ditemukan adanya gejala klinis tumor ganas tiroid dan pemeriksaan fungsi tiroid normal selama 6-12 bulan setelah tatalaksana differentiated thyroid carcinoma dengan tiroidektomi disertai atau tanpa radiasi, maka baru bisa dinyatakan disease-free-stage. ${ }^{20}$

\section{SIMPULAN}

Diagnosis low risk papillary thyroid carcinoma dapat ditegakkan berdasarkan anamnesis, pemeriksaan fisik, dan pemeriksaan diagnostik lainnya (USG, FNAB, CT Scan). Pemeriksaan FNAB memiliki peranan penting dalam menegakkan suatu keganasan, namun pemeriksaan histopatologi adalah pemeriksaan gold-standard untuk diagnosis varian tumor ganas tiroid. Penatalaksanaan papillary thyroid carcinoma menurut NCCN 2017 tergantung pada indikasinya. Sebagian besar PTC memiliki prognosis yang baik, namun tetap dianjurkan untuk kontrol secara periodik.

\section{DAFTAR PUSTAKA}

1. Katoh H, Yamashita K, Enomoto T, Watanabe M. Annals of clinical pathology classification and general considerations of thyroid cancer. Ann Clin Pathol. 2015;3(1):1-9.

2. Kitahara CM, Sosa JA. The changing incidence of thyroid cancer. Edisi ke-5. New York: Nat Publ Gr; 2016.

3. Shah J. Thyroid malignancy. In: Mahadevaiah J, Johnson B, editor (penyunting). Head and neck surgery and oncology. Edisi ke-4. Pittsburg: Elsevier; 2012.hlm.115-20

4. Desrochers A. Thyroid. In: Boyle A. Schwartz's Principles of Surgery. Edisi ke-11.Chicago:Mc Graw Hill; 2013.hlm.2134-40

5. Myers Y. Thyroid. In: Davidson L, Mikayla S. KJ Lee's essential otolaryngology head and neck surgery. Edisi ke-11. Washington: Johnson Press;2016.hlm.234-42.

6. Johnson J, Rosen C. Neck Malignancy. Dalam: George B, Roven S, editor (penyunting). Bailey's 
head \& neck surgery. Edisi ke-5. Lippincott: Williams\& Wilkins; 2014.hlm.1276-80.

7. Brent GA. Science in medicine Mechanisms of thyroid hormone action. Mod Pathol. 2012; 122 (9): 3035-43.

8. Heart B. Physiological and molecular basis of thyroid hormone action. Otolaryngologic Clinics of North America. 2018;81(3):1097-42.

9. Browning S. Neck Cancer. Dalam: Benedikt S, Shah J, editor (penyunting). Scott-Brown's Otorhinolaryngology Head and Neck Surgery. Edisi ke-2. London: Arnold Press; 2008.hlm.256-62.

10. Shah JP. Thyroid carcinoma: Epidemiology, histology, and diagnosis. Clin Adv Hematol Oncol. 2015;13(4):3-6.

11. Livolsi VA. Papillary thyroid carcinoma: An update. Mod Pathol. 2011;24(S2):S1-S9.

12. Demir A. the Bethesda system for reporting thyroid. Thyroid and The American Journal of Clinical Pathology. 2017;27(11):1341-6.

13. American Joint Committee on Cancer (AJCC) Staging Manual. Staging Thyroid. Pittsburg: Elsevier; 2009.

14. Shin JH. Ultrasonographic imaging of papillary thyroid carcinoma variants. Radiology Case Report Journals. 2017;36(4):103-10.

15. Verburg F a, Mäder U, Kruitwagen CLJJ, Luster M, Reiners C. A comparison of prognostic classification systems for differentiated thyroid carcinoma. Clin Endocrinol (Oxf). 2010; 72 (6): 830-8.

16. The National Comprehensive Cancer Network (NCCN). Thyroid carcinoma. New York: Elsevier; 2015.

17. Karakozis S. Management of Complications after Thyroid Surgery. Injury of Recurrent Laryngeal Nerve, Major Thoracic Duct,Trachea, Oesophagus and Postoperative Bleeding. Hell J Surg. 2015;871(87):115-7.

18. Mahmud Gauhar T. Papillary Thyroid Carcinoma. J Thyroid Disord Ther. 2014;3(1):34-7.

19. Matsuzu K, Sugino K, Masudo K. Thyroid lobectomy for papillary thyroid cancer: Long-term follow-up study of 1,088 cases. World J Surg. 2014;38(1):68-79.

20. Schmidbauer B, Menhart K, Hellwig D, Grosse J. Differentiated thyroid cancer-treatment: State of the art. Int J Mol Sci. 2017;18(6):1-17. 